\title{
GERMANY-INDONESIA AGRICULTURAL TRADE: RECENT DEVELOPMENT AND POSSIBLE FUTURE DIRECTIONS
}

\author{
Anastasia Asri Widyasari ${ }^{* * *)}$, Stephan von Cramon-Taubadel ${ }^{*}$, Suharno**), and \\ Rita Nurmalina**) \\ *) Department of Agricultural Economics and Rural Development, Georg-August-Universität Göttingen \\ Platz der Göttingen Sieben 5 37073, Göttingen, Germany \\ ${ }^{* *}$ Department of Agribusiness, Faculty of Economics and Management, IPB University \\ Jl. Kamper Wing 4 Level 5 Kampus IPB, Dramaga16680 Bogor, Indonesia
}

\begin{abstract}
To understand the recent development and to anticipate the future directions and trends of agricultural trade between Germany and Indonesia, this study analyzed the data of agricultural trade between the Germany and Indonesia. The major agricultural commodities that are traded between those countries are crude palm oil (CPO) and skimmed milk powder (SMP). There were public policies and environmentalist group movements that may have influenced the agricultural trade volumes within the period. This study identified those two factors. This study also identified possible future directions and trends of agricultural trade between the two countries. It analyzed the data ranged from 2001 to 2018, which were obtained from ITC Trade Map and analyzed using multiple regression models. The findings were in 2001-2018, the CPO and SMP trade between those countries showed an upward trend. However, it was predicted in the future that the public policies and environmentalist group movements might cause the agricultural trade to decrease. The world production quantity of CPO and the production of CPO in Indonesia had a significant effect on the German import from Indonesia, whereas the production quantity of milk in Indonesia and the GDP of Indonesia had a significant impact on the German export to Indonesia. The future directions and trend of German CPO import from Indonesia and German SMP export to Indonesia show an increase both for quantity and value.
\end{abstract}

Keywords: agricultural trade, recent development, future directions

\begin{abstract}
Abstrak: Untuk memahami perkembangan terkini dan untuk mengantisipasi arah dan tren perdagangan pertanian dimasa depan antara Jerman dan Indonesia, penelitian ini menganalisis data perdagangan pertanian antara Jerman dan Indonesia. Komoditas pertanian utama yang diperdagangkan antara negara-negara tersebut adalah minyak sawit mentah (CPO) dan susu bubuk skim (SMP). Ada beberapa kebijakan publik dan gerakan kelompok pencinta lingkungan yang mungkin memengaruhi volume perdagangan pertanian dalam periode tersebut. Penelitian ini mengidentifikasi dua faktor tersebut. Penelitian ini juga mengidentifikasi kemungkinan arah masa depan dan tren perdagangan pertanian antara kedua negara tersebut. Penelitian ini menganalisis data dengan periode dari 2001 hingga 2018, yang diperoleh dari ITC Trade Map dan dianalisis menggunakan model regresi berganda. Hasil penelitian ini adalah pada tahun 2001-2018, perdagangan CPO dan SMP antara negara-negara tersebut menunjukkan tren kenaikan. Namun, diperkirakan di masa depan bahwa kebijakan publik dan gerakan kelompok pencinta lingkungan dapat menyebabkan perdagangan pertanian menurun. Kuantitas produksi CPO dunia dan produksi CPO di Indonesia berpengaruh signifikan terhadap impor Jerman dari Indonesia, sedangkan kuantitas produksi susu di Indonesia dan PDB Indonesia memiliki dampak signifikan terhadap ekspor Jerman ke Indonesia. Arah dan tren masa depan impor CPO oleh Jerman dari Indonesia dan ekspor SMP dari Jerman ke Indonesia menunjukkan peningkatan kuantitas dan nilai.
\end{abstract}

Kata kunci: perdagangan pertanian, perkembangan terkini, arah masa depan

\footnotetext{
${ }^{1}$ Corresponding author:

Email: a.widyasari@stud.uni-goettingen.de
} 


\section{INTRODUCTION}

International trade is an essential source of economic growth. It contributes $88.67 \%$ and $43.02 \%$ to German and Indonesian Gross Domestic Products (GDP), respectively (World Bank, 2020). The primary commodities in international trade between Germany and Indonesia are from the agricultural sector. There are 391 agricultural commodities that were exported from Germany to Indonesia and 405 agricultural commodities that were imported to Germany from Indonesia. Three major German agricultural exports to Indonesia are skimmed milk powder (SMP), whey, and tobacco. Indonesia still needs to improve the domestic production of milk as the input for dairy industries to produce SMP and meet the domestic needs. In contrast, three major German agricultural imports from Indonesia are crude palm oil (CPO), crude palm, kernel, and coffee (ITC Trade Map, 2020). The use of $\mathrm{CPO}$ in Germany is essential as a renewable energy sources, however Indonesian CPO is assumed to be unsustainable due to the deforestation.

The highest percentage of export share for SMP from Germany to Indonesia was in 2013, which accounted for $24.42 \%$ of the total agricultural commodities exported with the value of US $\$ 0.32$ billion and $17.65 \%$ for whey in 2015 with the value of US\$ 0.02 billion, followed by $9.16 \%$ for tobacco in 2017 with the value of US\$0.01 billion (ITC Trade Map, 2020). However, despite the high values of agricultural commodities exported from Germany to Indonesia, those values are much smaller compared to German agricultural imports from Indonesia.

CPO import share of Germany from Indonesia had the highest percentage in 2010 which represented 35.44\% of the total agricultural commodities imported with the value of US $\$ 0.38$ billion and for crude palm kernel was $25.78 \%$ in 2011 with the value of US $\$ 0.37$ billion, followed by coffee with the highest percentage in 2008 accounted for $16.34 \%$ with the value of US $\$ 0.22$ billion (ITC Trade Map, 2020).

The average total value of agricultural commodities exported by Germany to Indonesia within the period 2001-2018 was US $\$ 0.07$ billion, while the average total value of German agricultural import values from Indonesia in the same period was US\$0.88 billion that was almost twelve times higher than the export values.
There are several research projects conducted to analyze the factors that affect international trade, especially for agricultural commodities, such as $\mathrm{CPO}$ and SMP. Nibras (2019) examined the factors affecting Indonesian palm oil export to the Organization of Islamic Cooperation (OIC) countries. The results of the study indicated that the GDP per capita of the importer, the economic distance, the export price, the population of the importer, and the real exchange rate had a significant effect on the volume of Indonesian palm oil exports to the OIC countries.

Azizah's study (2015) examined the Indonesian CPO export to the EU in 2000-2011. The study showed that the CPO production and GDP of importer were variables that had a significant effect on Indonesian CPO exports.

Maygirtasari et al. (2015) observed the determinants that affect the volume of Indonesian CPO export by using variables of domestic $\mathrm{CPO}$ production, domestic $\mathrm{CPO}$ prices, international $\mathrm{CPO}$ prices, and exchange rates. The results showed that the domestic CPO production, domestic $\mathrm{CPO}$ prices, and exchange rates had a significant effect on Indonesian CPO export volume.

Several recent studies have analyzed the factors that affect international trade on SMP. Amaliah (2008) observed the factors affecting Indonesian import from 1976 to 2005. The results of this research showed that Indonesian milk imports, in the long run, were significantly affected by the real import price of milk, the domestic price of milk, the real exchange rates, and per capita income. Indonesian milk imports in the short run were significantly affected by domestic milk production, real import price of milk, per capita income, real exchange rates, and deletion of import ratio policy.

Pratiwi and Hakim (2013) analyzed the behavior of milk imports in Indonesia during 1985-2010. The results showed that in the long run, factors influencing the milk import were per capita income, domestic milk real price, and imported milk price. While, in the short run, the import was influenced by population size of more than five-year-old residents, real domestic price milk, the real price of imported milk, and exchange rates. 
Despite the seemingly ample information available, research to date on international trade has focused to one country which exports one commodity in which has a comparative advantage to another country. The research does not capture the international trade in specific sector like agricultural commodities between two countries.

To anticipate the future directions and trends of agricultural trade between Germany and Indonesia, in this case is CPO and SMP, this paper intends to carefully analyze the data of international trade between the two countries in the period of 2001-2018. Within the period, there were events and public policies that may have influenced the agricultural trade volumes. This paper also intends to identify those events and policies. The third objective of this study is to identify possible future directions and trends of agricultural trade between the two countries.

\section{METHODS}

The data used in this study is secondary time-series data. The time-series data include the annual data from 2001 to 2018. The data used were obtained from ITC Trade Map (2020) and analyzed using multiple regression models.
There are some determinants that influence the German import of CPO from Indonesia based on the demand and supply sides. On the demand side, the import of CPO is affected by (1) CPO as biodiesel and vegetable oil consumption in Germany, (2) GDP per capita of Germany, and (3) population of Germany. On the supply side, the export of CPO is influenced by (1) CPO world price and production, (2) production of $\mathrm{CPO}$ in Indonesia, (3) exchange rate, and (4) soybean oil world price and production (Table 1). The regression model of CPO import by Germany from Indonesia is as follows:

$$
\begin{aligned}
\mathrm{QM}_{\mathrm{it}}= & \alpha+\beta \mathrm{BIO}_{\mathrm{it}}+\beta \mathrm{W}_{\mathrm{t}}+\beta \mathrm{QW}_{\mathrm{t}}+\beta \mathrm{QPROD}_{\mathrm{jt}}+\beta \mathrm{ER}_{\mathrm{jt}}+ \\
& \beta \mathrm{GDP}_{\mathrm{it}}+\beta \mathrm{POP}_{\mathrm{it}}+\beta \mathrm{PWSBO}_{\mathrm{t}}+\beta \mathrm{QWSBO}_{\mathrm{t}}+\mathrm{e}_{\mathrm{ijt}}
\end{aligned}
$$

There are some determinants that influence the German export of SMP to Indonesia based on the demand and supply side. On the demand side, the import of SMP is affected by (1) GDP of Indonesia, (2) population of Indonesia, and (3) Oceania price of SMP. On the supply side, the export of SMP is influenced by (1) SMP world price and production and (2) exchange rate (Table 2). The regression model of SMP export from Germany to Indonesia is as follows:

$$
\begin{gathered}
\mathrm{QX}_{\mathrm{it}}=\alpha+\beta \mathrm{PW}_{\mathrm{t}}+\beta \mathrm{QW}_{\mathrm{t}}+\beta \mathrm{QMPROD}_{\mathrm{jt}}+\beta \mathrm{ER}_{\mathrm{jt}}+ \\
\beta \mathrm{GDP}_{\mathrm{jt}}+\beta \mathrm{POP}_{\mathrm{jt}}+\beta \mathrm{PO}_{\mathrm{t}}+\mathrm{e}_{\mathrm{ijt}}
\end{gathered}
$$

\begin{tabular}{|c|c|c|c|c|}
\hline Variable & Label & Unit & Period & Source \\
\hline $\begin{array}{l}\mathrm{QM}_{\mathrm{it}}(\text { dependent } \\
\text { variable) }\end{array}$ & $\begin{array}{l}\text { CPO import value from Germany to } \\
\text { Indonesia }\end{array}$ & US\$ & Annually & ITC Trade Map \\
\hline $\mathrm{BIO}_{\mathrm{it}}$ & $\begin{array}{l}\mathrm{CPO} \text { as biodiesel consumption in } \\
\text { Germany }\end{array}$ & tons & Annually & UFOP \\
\hline $\mathrm{PW}_{\mathrm{t}}$ & $\mathrm{CPO}$ world price & US\$/ton & Annually & FAO \\
\hline $\mathrm{QW}_{\mathrm{t}}$ & $\mathrm{CPO}$ world production & tons & Annually & FAO \\
\hline QPROD $_{\mathrm{jt}}$ & $\mathrm{CPO}$ production in Indonesia & tons & Annually & Central Bureau of Statistics \\
\hline $\mathrm{ER}_{\mathrm{jt}}$ & Exchange rate of US Dollar to Rupiah & Rp/US\$ & Annually & European Central Bank \\
\hline $\mathrm{GDP}_{\text {it }}$ & $\begin{array}{l}\text { GDP per capita of Germany (current } \\
\text { US\$) }\end{array}$ & US\$ & Annually & World Bank \\
\hline $\mathrm{POP}_{\mathrm{it}}$ & Population of Germany & people & Annually & World Bank \\
\hline $\mathrm{PWSBO}_{\mathrm{t}}$ & Soybean oil world price & US\$/ton & Annually & FAO \\
\hline $\mathrm{QWSBO}_{\mathrm{t}}$ & Soybean oil world production & tons & Annually & FAO \\
\hline
\end{tabular}

Table 1. Data description of German CPO imported from Indonesia 
Table 2. Data description of German SMP exported to Indonesia

\begin{tabular}{llccl}
\hline Variable & Label & Unit & Period & Source \\
\hline $\begin{array}{l}\mathrm{QX}_{\mathrm{it}}(\text { dependent } \\
\text { variable) }\end{array}$ & SMP export quantity from Germany to Indonesia & tons & Annually & ITC Trade Map \\
$\mathrm{PW}_{\mathrm{t}}$ & SMP world price & US\$/ton & Annually & FAO \\
$\mathrm{QW}_{\mathrm{t}}$ & SMP world production & tons & Annually & FAO \\
$\mathrm{ER}_{\mathrm{jt}}$ & Exchange rate US Dollar to Rupiah & $\mathrm{Rp} / \mathrm{US} \$$ & Annually & Bank of Indonesia \\
$\mathrm{GDP}_{\mathrm{jt}}$ & GDP per capita of Indonesia (current US\$) & $\mathrm{US} \$$ & Annually & World Bank \\
$\mathrm{POP}_{\mathrm{jt}}$ & Population of Indonesia & people & Annually & World Bank \\
$\mathrm{PO}_{\mathrm{t}}$ & SMP Oceania price & US\$/ton & Annually & FAO \\
\hline
\end{tabular}

\section{RESULT}

\section{Development of German CPO Import from Indonesia}

Figure 1 shows the import value and volume of CPO by Germany from Indonesia with the period of 20012018. The average growth of the import quantity over the last twenty years was $4.71 \%$. The CPO imported by Germany from Indonesia in the previous twenty years showed the inverted U-shaped curve. This is because there was a financial crisis in 2008/2009 (ITC Trade Map, 2020). Owing to the global financial market crisis, economic growth in all regions in the world has been slowing rapidly and synchronously, including the GDP of Germany. According to the World Bank (2020), the GDP per capita of Germany fell in 2009, with a growth rate of $-8.69 \%$ compared to the previous year. The import volume of CPO by Germany increased in 2009 as of 0.48 million tons, despite the falling of the GDP per capita, and the world market prices for CPO peaked. This is because the demand for price elasticity of Indonesian CPO is inelastic, as CPO is a necessity for large parts of the food processing industry (40\%) (Abdullah, 2011). In addition, CPO is used in the manufacture of soap, detergent, and so on. Therefore, increases in CPO prices do not significantly impact the quantity consumed.

The highest value of CPO imported by Germany from Indonesia was in 2010, which accounted for 0.38 US\$ billion. The reason for this is because of the price of $\mathrm{CPO}$ in the world market continued to rise in that period. According to Food and Agriculture Organization (FAO) (2020), the world price of CPO in 2010 increased $31.93 \%$ or from US\$682.83 per ton to US $\$ 900.83$ per ton compared to the previous year. The trigger for the increase in the price of CPO was none other than an increase in demand that occurred as the global economic recovery.

\section{Development of German SMP Export to Indonesia}

Figure 2 shows the export value and volume of SMP by Germany to Indonesia in 2001-2018. The average growth of the export quantity over the last twenty years was $42.23 \%$. The lowest value and volume of German SMP export to Indonesia was in 2008 during the previous twenty years, accounted for US\$1.06 million and 0.33 million tons, respectively. This is due to the global economic crisis. Unlike CPO, the 2008 global financial crisis had a negative impact on SMP export from Germany to Indonesia. It sharply reduced the demand for SMP import. In that year, the volume of Indonesian SMP imports decreased by $87 \%$.

\section{The Effects of Public Policy on CPO and SMP Trade between Germany and Indonesia}

The European Parliament (EP) and the Council on April 23rd, 2009 promoted the use of renewable energy sources and set an ambitious target, i.e. the share of energy from renewable sources must rise to $20 \%$ by 2020. The Renewable Energy Directive (RED) 2009 is the main instrument to reach this target. This created an increase in demand for palm oil as a biofuel feedstock in the EU. However, it has been alleged that the palm oil-based biofuel production and related forests and peatlands conversions would result in even higher global emissions than those from the conventional fossil fuels that were supposed to be avoided (Butler, 2008). Indonesian oil palm growth was also related to forest fires that lead to transboundary smoke haze pollution (German et al. 2011). 


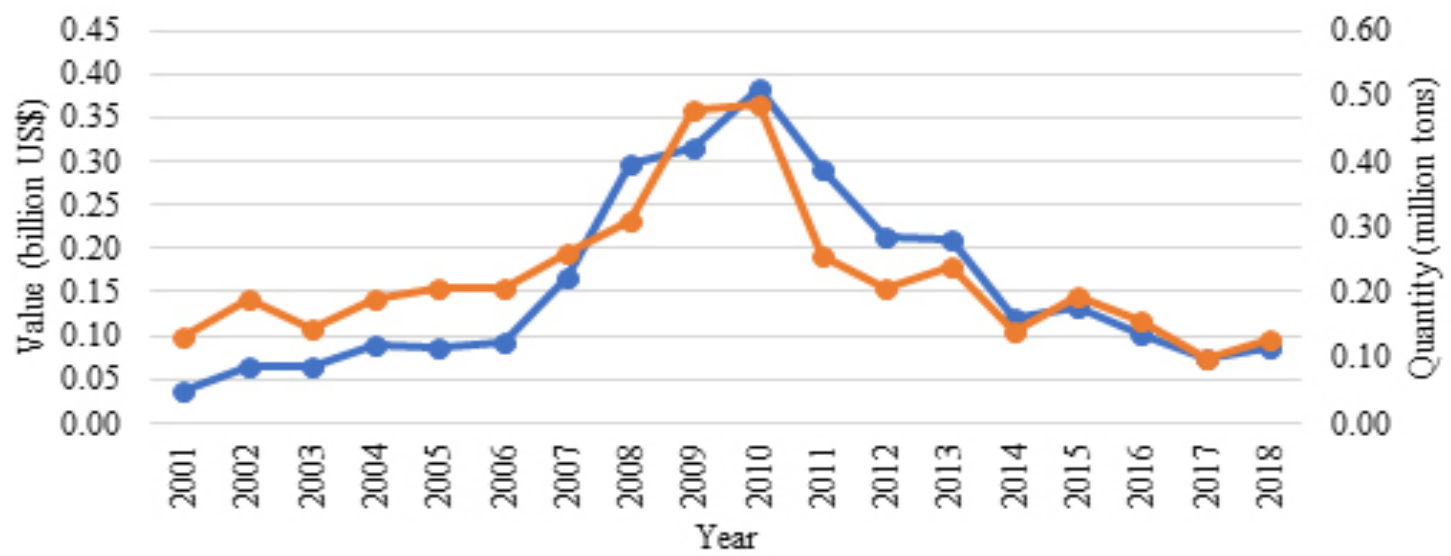

$\multimap$ Value of crude palm oil $\longrightarrow$ Quantity of crude palm oil

Figure 1. German CPO import from Indonesia (ITC Trade Map, 2020)

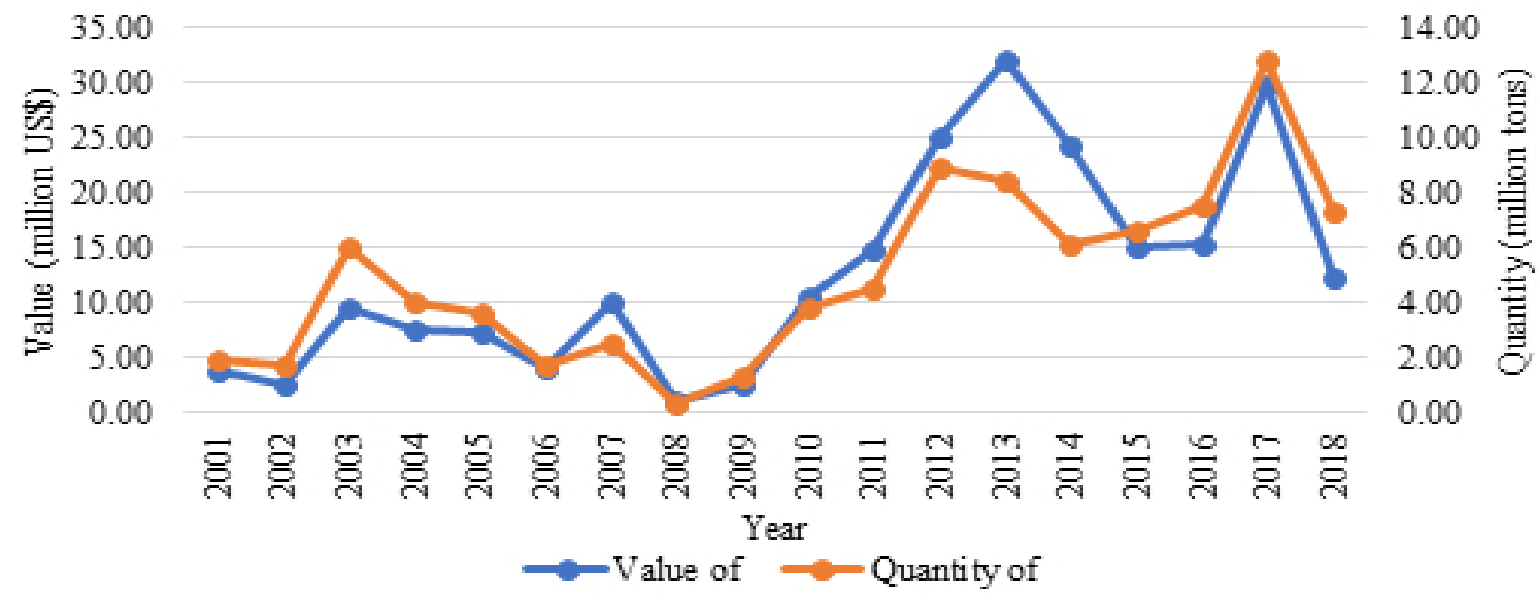

Figure 2. German SMP export to Indonesia (ITC Trade Map, 2020)

After discussions (and campaigns of major palm oilproducing countries), in 2012, when it was certified in the framework of the Roundtable on Sustainable Palm Oil (RSPO), the European Commission (EC) decided to consider palm oil-based biodiesel as sustainable in the context of RED 2009 (Yaghoob et al. 2017). The RSPO was established in 2004 with more than 3000 members worldwide based on the engagement of multistakeholder. It has created a set of specific sustainability standards that companies must meet to produce the Certified Sustainable Palm Oil (CSPO). This EC move will increase the exports of RSPO certified palm oil into Europe, as palm oil is subject to favorable treatment over other crop-based biofuels (Butler, 2012), but the fraction of certified Indonesian palm oil plantations remains small (Focus Asean, 2016).
In 2016, EC proposed an update of the RED 2009 for the period from 2021 to 2030 (called as RED II), and a final compromise document was agreed among European institutions on June 14th, 2018. RED II prohibits raw materials, like biofuel, bioliquid, etc. that are considered to have a high indirect land-use change (ILUC). Biofuel (biodiesel and renewable diesel) is produced from fats and vegetable oils, such as palm oil, rapeseed oil, and soybean oil. The import of palm oil to the EU will be prohibited and will gradually reduce to zero by 2030 since it is assumed to be the cause of deforestation by five million hectares in the period from 2008 to 2016.

The EU claimed that the ban was due to environmental concerns; however, with a closer assessment, it appears that the principal motivation was the European domestic interests (Astra Agro Lestari, 2017). The 
CPO contributes a massive amount to EU vegetable oil consumption, which accounted for $89 \%$ of the overall imports of such commodities based on the Indonesian Palm Oil Association (IPOA). According to ITC Trade Map (2020), Indonesian palm oil is mainly entering the EU, and the EU is the second-largest market for Indonesian palm oil (after India). The objectives of the Delegated Act are to separate palm oil from the renewable sector to the advantage of rapeseed oil and other less competitive vegetable oils produced in EU member states. Within the palm oil industry, it is generally believed that this Delegated Act promotes political and economic protectionism, whereby the EU uses environmental issues for its purposes instead of making science-based decisions.

In response to the discrimination over the $\mathrm{CPO}$ by the $\mathrm{EU}$, Indonesian government confirms its commitment that the commodity will be used more for domestic needs with the implementation of Biodiesel $30 \%$ or B30 program, a blend of $30 \%$ by volume biodiesel produced from palm oil with $70 \%$ by volume petroleum diesel. This policy will lead to the decline of CPO export to the EU, including Germany since the production will prioritize the domestic demand. The government believes that it will save the foreign exchange up to US $\$ 4.03$ billion. There are three reasons why the use of the B30 program needs to be promoted in Indonesia. First, Indonesia must find renewable energy sources to release dependence on fossil energy. Second, to reduce reliance on oil and gas imports, so that they can support Indonesia's energy independence and security. Third, it will increase the domestic demand for CPO, thus double the benefits to the farmers (Tempo, 2019).

Besides the RED II that will be implemented by the $\mathrm{EP}$, another blow regarding $\mathrm{CPO}$ is the countervailing duties of $8-18 \%$ on imports of subsidized biodiesel from Indonesia by the EU in 2019. The EU tariffs follow an anti-subsidy investigation against Indonesian biodiesel producers launched in December 2019 following a complaint by the European Biodiesel Board. The EC said in a statement that the investigation showed that Indonesian biodiesel producers benefit from grants, tax benefits, and access to raw materials below market prices.

In response to the EU targeting the palm oil-based biodiesel, the Indonesia Minister of Trade would recommend to an inter-ministerial team a $20-25 \%$ tariff on EU dairy products. Also, he had asked dairy product importers to find sources of supply outside the European member states (DW, 2019). The Indonesian Food and Beverage Association (GAPMMI), expressed its disapproval regarding the new tariff on dairy products. GAPMMI assessed that the implementation of the imposition of import tariff duties have the potential to increase domestic prices because it limits existing availability alternatives and reduces consumer purchasing power (Republika, 2019).

In conclusion, the RED 2009, the RED II, the countervailing duties regulations in the $\mathrm{EU}$, and the $\mathrm{B} 30$ program tend to have a negative impact on agricultural trade between Germany and Indonesia. However, public policies seem to significantly impact the German CPO import from Indonesia. The demand for CPO will continue to increase even though the regulations are menacing Indonesia. Also, the imposition of import tariff on dairy products as a response to the discrimination over the CPO will likely have an insignificant effect on German SMP export to Indonesia. The potential increase in the domestic price of milk Indonesia due to the tariff duties will likely not decrease the demand for SMP by the importer. The reason for this is the production of milk as input in Indonesia is low and cannot meet the needs of dairy industries.

\section{The Effects of Environmentalist Group Movements on CPO Imported by Germany from Indonesia}

Several environmentalist groups are campaigning and giving pressure to palm oil industries. Indonesia is the most significant exporter of CPO over the last twenty years. Greenpeace's anti-palm oil campaign brought many losses and disadvantages for the Indonesia economy since Indonesian CPO export has shown a lot of benefits to Indonesia economic growth. Many multinational companies decide to stop buying palm oil from Indonesia; additionally, it might also lead to the decline of CPO imported by Germany from Indonesia. The environmental damage problem is an impediment to the Indonesia palm oil industry's growth. Greenpeace, an international environmental non-governmental organization (NGO), openly campaigns to ensure that companies do not produce or trade in palm oil that

sacrifices forests and peatlands. In November 2007, Greenpeace released an article entitled that includes accusations made by Greenpeace against the Indonesian palm oil industry. They said that it was the source of 
global greenhouse gas (GHG) emissions from land-use change and deforestation. In the article, it mentioned that the GHG emissions by degradation and burning of Indonesia's peatlands putting Indonesia in third-ranked as the producer of GHG emissions after the USA and China (Greenpeace, 2007).

The decreasing reputation of Indonesia palm oil in the international market is another impact caused by the Greenpeace campaign. Various environmental issues alleged by Greenpeace, such as peatland, deforestation, land and forest fires, GHG effect, extinction of the orangutan habitats, and climate change, have made consumers trust to Indonesian CPO production decline. The IPOA said that the Greenpeace anti-palm oil movement does not have any significant direct effect on the export of palm oil to the EU (Sasmi, 2018). In 2005-2009, CPO export volume to the EU decreased, but Indonesian palm oil demand continues to increase. Indonesian palm oil producers threaten to stop exporting $\mathrm{CPO}$ to the EU because of the number of regulations imposed in the EU. By the end of the day, however, the importers asked to purchase the CPO from Indonesia again.

In conclusion, the environmentalist groups like Greenpeace lead to the decision of many multinational companies to stop importing CPO from Indonesia. Nonetheless, the Greenpeace anti-palm oil campaign will likely not have any significant direct effect on the CPO exported by Indonesia to the EU, including Germany. Although there are several regulations imposed in the EU that are discriminating over $\mathrm{CPO}$ and threaten Indonesia to stop exporting CPO to the $\mathrm{EU}$, by the end of the day, the demand for CPO seems to remain increase to meet the needs of $\mathrm{CPO}$ as a necessity suitable for large parts of the food processing industry.

\section{Factors Affecting the German CPO Imported from Indonesia}

As shown in Table 3, world production of $\mathrm{CPO}$ has a negative coefficient, which implies that if $\mathrm{CPO}$ world production increases by one ton, ceteris paribus, the import volume of CPO by Germany from Indonesia will decrease by 0.03 ton, on average. In other words, an increase in world production of CPO will reduce the demand for CPO in Germany. This might be caused by the preference of Germany in importing CPO. They prefer to import $\mathrm{CPO}$ from other $\mathrm{CPO}$ exporting countries that have certified sustainable palm oil (CSPO) and are also members of RSPO. Malaysia, Guatemala, Colombia, Honduras, and Thailand are members of RSPO (RSPO, 2020). Indonesia still has a low fraction of certified palm oil plantations (Focus Asean, 2016).

Also, the production quantity of $\mathrm{CPO}$ in Indonesia has a positive coefficient, which means that if $\mathrm{CPO}$ production quantity in Indonesia increase by one ton, ceteris paribus, the import volume of CPO by Germany from Indonesia will also increase by 0.09 ton, on average. As for this, the supply curve shifts to the right and increase the quantity of traded, so that so that the import volume of $\mathrm{CPO}$ will also rise.

\section{Factors Affecting the German SMP Export to Indonesia}

Table 4 shows that the GDP of Indonesia has a positive coefficient implying that if Indonesian GDP increases by US $\$ 1$, ceteris paribus, the export volume of SMP by Germany to Indonesia will also rise by US $\$ 0.003$, on average. The reason for this is that the increase in the GDP of Indonesia, which indicates the purchasing power will make the demand for SMP from Indonesia higher and raise the export volume of SMP. The reason for this is that the increase in the GDP of Indonesia will make the demand for SMP from Indonesia higher and raise the export value of SMP.

\section{The Forecast of Future Directions and Trends}

For forecasting, the quantity and value of German CPO import from Indonesia and German SMP export to Indonesia, the least-squares method is used. The forecasted volume and value are for the year of 2025. The value of each explanatory variable $\left(\mathrm{x}_{\mathrm{t}}\right)$ for the year of 2025 is forecasted exogenously using simple linear regression with the following equation.

$$
x_{t}=\alpha+\beta_{t}
$$

Where: $\mathrm{x}_{-} \mathrm{t}$ is each of the nine independent variables of model 1 and 2, and seven independent variables of model 3 and 4 for the selected value of $t ; \alpha$ is the $\mathrm{x}$-intercept. It is the estimated value of $\mathrm{x}$ where the line crosses the $Y$-axis when $t$ is zero; $\beta$ is the slope of the line or the average change in $\mathrm{x}_{-} \mathrm{t}$ for each increase of one unit in $t$; $t$ is the value of time from 2001 to 2025 $(\mathrm{t}=1, \ldots, 25)$. 
Table 3. Analysis result of factors affecting German CPO quantity import from Indonesia

\begin{tabular}{|c|c|c|c|c|}
\hline Variable & Coefficient & Std. Error & t-ratio & $\mathrm{p}$-value \\
\hline const & $-6.45370 \mathrm{e}+06$ & $5.78032 \mathrm{e}+06$ & -1.116 & 0.2966 \\
\hline $\mathrm{BIO}_{\mathrm{it}}$ & 0.0561493 & 0.0502690 & 1.117 & 0.2964 \\
\hline $\mathrm{PW}_{\mathrm{t}}$ & 0.855325 & 837.345 & 0.001021 & 0.9992 \\
\hline $\mathrm{QW}_{\mathrm{t}}$ & -0.0319158 & 0.0150997 & -2.114 & $0.0675^{*}$ \\
\hline $\mathrm{QPROD}_{\mathrm{jt}}$ & 0.0859660 & 0.0319988 & 2.687 & $0.0276^{* *}$ \\
\hline $\mathrm{ER}_{\mathrm{jt}}$ & -30.4386 & 43.7895 & -0.6951 & 0.5067 \\
\hline $\mathrm{GDP}_{\mathrm{it}}$ & -22.0627 & 13.9365 & -1.583 & 0.1521 \\
\hline $\mathrm{POP}_{\mathrm{it}}$ & 0.0953596 & 0.0707881 & 1.347 & 0.2149 \\
\hline $\mathrm{PWSBO}_{\mathrm{t}}$ & 512.314 & 726.461 & 0.7052 & 0.5007 \\
\hline $\mathrm{QWSBO}_{\mathrm{t}}$ & -0.0213143 & 0.0158093 & -1.348 & 0.2145 \\
\hline
\end{tabular}

Table 4. Analysis result of factors affecting German SMP quantity import from Indonesia

\begin{tabular}{lcccc}
\hline \multicolumn{1}{c}{ Variable } & Coefficient & Std. Error & t-ratio & p-value \\
\hline const & 50354.2 & 60890.3 & 0.8270 & 0.4275 \\
$\mathrm{PW}_{\mathrm{t}}$ & 0.804904 & 6.75562 & 0.1191 & 0.9075 \\
$\mathrm{QW}_{\mathrm{t}}$ & 0.00155401 & 0.00535895 & 0.2900 & 0.7778 \\
$\mathrm{QMPROD}_{\mathrm{jt}}$ & -0.0220511 & 0.0125883 & -1.752 & 0.1104 \\
$\mathrm{ER}_{\mathrm{jt}}$ & -0.163250 & 0.921473 & -0.1772 & 0.8629 \\
$\mathrm{GDP}_{\mathrm{jt}}$ & $3.18176 \mathrm{e}-08$ & $1.54230 \mathrm{e}-08$ & 2.063 & $0.0661^{*}$ \\
$\mathrm{POP}_{\mathrm{jt}}$ & -0.000198240 & 0.000287894 & -0.6886 & 0.5067 \\
$\mathrm{PO}_{\mathrm{t}}$ & -2.59818 & 6.35647 & -0.4087 & 0.6913 \\
\hline
\end{tabular}

Note: $\mathrm{QX}_{\mathrm{it}}$ is the dependent variable, $\mathrm{R}^{2}=0.70$; ${ }^{*}$ Significant at $10 \%$ level of probability

The quantity of CPO imported by Germany from Indonesia in 2018 was accounted for 0.13 million tons, and in 2025 is predicted to be 0.43 million tons. While the value of German CPO import from Indonesia in 2018 was US $\$ 0.09$ billion and in 2025 is forecasted to be US\$0.41 billion. This means that the empirical analysis result of the future direction and trend of the import shows an increase in both quantity and value. However, the theoretical analysis based on the effects of public policy and environmentalist groups movement mentioned above indicates that German CPO import from Indonesia is predicted to fall in the future. The reason for this might be caused by the implementation of the public policy like RED II started from 2021, or the campaign of the environmentalist groups that are predicted to have a negative impact on CPO imported by Germany from Indonesia will be delayed after the year of 2025. In other words, the demand for CPO from the EU member states will still increase for the next five years despite the public policy or movement.
The quantity of German SMP export to Indonesia in 2018 was accounted for 7.3 thousand tons, and in 2025 is forecasted to be 0.02 million tons. In contrast, the value of SMP exported by Germany to Indonesia in 2018 was US $\$ 0.01$ billion, and in 2025 is predicted to be US\$0.05 billion. This implies that the future prediction and trend of the German export of SMP to Indonesia also shows an increase both for quantity and value. The reason for this is because of the dairies in Indonesia prefer to use imported milk as input in the production process due to the lower quality and higher price of domestic milk.

\section{Managerial Implications}

The results of this study have managerial implications for $\mathrm{CPO}$ and milk producers in Indonesia. For CPO producers, there are several efforts in facing the possibility of a decline in the future CPO imports, such as (1) operating CPO conference, (2) advocating 
Indonesian $\mathrm{CPO}$ through cooperation with the Indonesian Embassy abroad, (3) formulating the Indonesian Sustainable Palm Oil (ISPO) policy, (4) developing the CPO downstream Industry, and (5) implementing the $\mathrm{CPO}$ revitalization program. For milk producers, several ways to improve the quality and production of milk are providing high quality feeds, and regularly check animals for sign of disease.

\section{CONCLUSIONS AND RECOMMENDATIONS}

\section{Conclusions}

The findings in this paper for the first and second research questions are that in 2001-2010, the German CPO imported from Indonesia showed an upward trend. The RED 2009 and environmentalist group movements might be the reason for this decline. The public policy promoted the use of renewable energy sources in the EU. Nevertheless, the production of palm oil-based biodiesel is assumed to be the cause of deforestation. The EC decided to consider the biodiesel as sustainable in the context of RED 2009 if it is certified in the framework of RSPO. Even so, only a few of palm oil plantations in Indonesia that have been certified. Moreover, the Indonesian government attempts to prioritize more on the domestic needs of $\mathrm{CPO}$ by implementing the B30 program.

The environmentalist groups like Greenpeace is campaigning to ensure that companies do not produce or trade in palm oil that sacrifices forests and peatlands. This campaign leads to the decision of many multinational companies to stop importing CPO from Indonesia. Nonetheless, the Greenpeace anti-palm oil campaign does not have any significant direct effect on the CPO exported by Indonesia to the EU, including Germany. Although there are several regulations imposed in the EU that are discriminating over $\mathrm{CPO}$ and threaten Indonesia to stop exporting $\mathrm{CPO}$ to the $\mathrm{EU}$, by the end of the day, the demand for CPO will remain increase to meet the needs of CPO as a necessity suitable for large parts of the food processing industry. Another finding for the first research is that the German SMP exported to Indonesia showed the ascending trend over the last twenty years. The average growth rate of SMP export was accounted for $42.23 \%$. Furthermore, the future prediction and trend of the German export of SMP to Indonesia shows an increase both for quantity and value.

\section{Recommendations}

For future studies, it can be recommended the use of more samples to identify factors affecting international trade to obtain better results without any multicollinearity. Finally, it may be useful to analyze other commodities besides CPO and SMP. Further detailed information on this, together with findings from other countries, would again be beneficial.

\section{REFERENCES}

Abdullah A. 2011. Determinants of Indonesian palm oil export: price and income elasticity estimation. Trends in Agricultural Economics 4(2):50-57. https://doi.org/10.3923/tae.2011.50.57.

Amaliah S. 2008. Analysis of factors affecting the competitiveness and import of Indonesian milk in the period of 1976-2005 [thesis]. Bogor: IPB University.

Astra Agro Lestari. 2017. EU palm oil ban more than environmental issue. https://www.astra-agro. co.id/en/2019/09/30/eu-palm-oil-ban-morethan-environmental-issue/ [3 Apr 2019].

Azizah N. 2015. Analysis of Indonesian crude palm oil (CPO) exports in the European Union in 20002011.Economics Development Analysis Journal 4(3):301-307.

Butler RA. 2012. EU OKs biofuels produced from certified palm oil. https://news.mongabay. com/2012/11/e-u-oks-biofuels-produced-fromcertified-palm-oil/ [3 Apr 2019].

[FAO] Food and Agriculture Organization. 2020. GIEWS FPMA Tool: Monitoring and Analysis of Food Prices. https://fpma.apps.fao.org/giews/ food-prices/tool/public/\#/home. [11 Oct 2019].

Focus Asean. 2016. How will Indonesia cope with slump in demand for palm oil? http://sea-globe. com/how-willindonesia-cope-slump-demandpalm-oil/. [3 Apr 2019].

Greenpeace. 2007. How the palm oil industry is cooking the climate. https://www.greenpeace.org/usa/ research/how-the-palm-oil-industry-is-c/.[3 Apr 2019].

[ITC Trade Map] International Trade Center Trade Map. 2020. Bilateral Trade between Germany and Indonesia. International Trade Center Trade Map. http://www.intracen.org/. [15 Oct 2019].

Maygirtasari T, Yulianto E, Mawardi MK. 2015. Factors affecting the volume of Indonesian crude palm 
oil (CPO) exports. Jurnal Administrasi Bisnis 25(2):1-8.

Nibras GS. 2019. Competitiveness, equivalent tariffs, and factors affecting Indonesian palm oil exports to OIC countries [thesis]. Bogor: IPB University.

Pratiwi H, Hakim A. 2013. Behavior of milk import in Indonesia. Telaah Bisnis 14(1):53-70.

Republika. 2019. European Union calls Indonesia's illegal import duty policy. https://republika.co.id/ berita/pxdvxo383/uni-eropa-sebut-kebijakanbea-masuk-indonesia-ilegal. [3 Apr 2020].

[RSPO] Roundtable on Sustainable Palm Oil. Search member. https://rspo.org/members/all. [28 Apr 2019].

Sasmi DT. 2018. The Impact of Greenpeace antipalm oil campaign towards Indonesian palm oil export to Europe in 2008-2010. Presented at Internationalization of Islamic Higher Education Institutions Toward Global Competitiveness, September 20-21, 2018, Semarang, Indonesia.

Tempo. 2019. B30: After Being Rejected by the European Union, Biodiesel Must be the Primary in Our Own Country? https://www.tempo. $\mathrm{co} / \mathrm{dw} / 1752 / \mathrm{b} 30$-setelah-ditolak-uni-eropabiodiesel-harus-jadi-primadona-di-negerisendiri. [3 Apr 2019].

World Bank. 2020. World bank open data. https://data. worldbank.org/. [11 Oct 2019].

Yaghoob J, Jamal O, Peter W, Sufian J. 2017. Risks and opportunities from key importers pushing for sustainability: the case of Indonesian palm oil. Agricultural and Food Economics 5(13):1-16. https://doi.org/10.1186/s40100-017-0083-z. 